\title{
Analisis Aplikasi Filter FIR dan Filter IIR dalam Pra-pemrosesan Sinyal Elektroensefalografi
}

\author{
Caroline $^{1}$, Nabila Husna Shabrina ${ }^{2}$, Melania Regina $\mathrm{Ao}^{3}$, Nadya Laurencya $^{4}$, Vanessa Lee ${ }^{5}$ \\ 1, 3, 4, 5 Teknik Fisika, Universitas Multimedia Nusantara, Tangerang, Indonesia \\ caroline@student.umn.ac.id \\ melania.regina@student.umn.ac.id \\ nadya.laurencya@student.umn.ac.id \\ vanessa.lee@student.umn.ac.id \\ ${ }^{2}$ Teknik Komputer, Universitas Multimedia Nusantara, Tangerang, Indonesia \\ nabila.husna@umn.ac.id
}

Diterima 21 Mei 2020

Disetujui 16 Juni 2020

\begin{abstract}
Electroencephalography (EEG) is a method used to analyze brain activities, detect abnormalities in brain, and diagnose brain-related disease. To extract information from EEG signal, preprocessing steps such as Fast Fourier Transform (FFT), filter, and wavelet decomposition will be needed. This paper primarily focuses on implementation of Finite Impulse Response (FIR) and Infinite Impulse Response (IIR) filter design in EEG signal preprocessing in MATLAB software. The result of the simulation indicates that each filter design implemented in EEG preprocessing has different performance and side effect toward signal processing parameters such as phase distortion, stability, Signal-toNoise Ratio (SNR), and running time. Filter design type implementation also affect power and entropy calculation result.
\end{abstract}

Index Terms-EEG, FIR Filter Digital, IIR Filter Digital, MATLAB, Wavelet Decomposition

\section{PENDAhuluaN}

Aplikasi dari filter digital banyak diterapkan diberbagai bidang dalam kehidupan sehari-hari. Salah satu implementasinya dalam bidang medis, yaitu dengan melakukan pra-pemrosesan sinyal elektroensefalografi atau dalam bahasa Inggris disebut electroencephalography (EEG). EEG mendeteksi gelombang otak untuk memastikan adanya perubahan fungsi otak yang menyebabkan kelainan pada otak.

Pada keadaan yang sebenarnya sinyal EEG masih terdapat kebisingan (noise), sehingga dibutuhkan digital filter guna menghilangkan noise tersebut. Pada project mata kuliah Pengolahan Sinyal Digital, dalam menghilangkan noise dari data sinyal EEG, akan digunakan wavelet decomposition, serta filter digital jenis FIR Hamming Window dan IIR Butterworth untuk memfilter frekuensi tinggi.
Penelitian terdahulu oleh Anshul, et. al yang bejudul "Performance Analysis of IIR \& FIR Windowing Techniques in Electroencephalography Signal Processing" membandingkan performa filter FIR dan IIR dalam pemrosesan sinyal EEG dengan menggunakan parameter Mean Square Error (MSE), Mean Absolute Error (MAE), Signal-to-Noise Ratio (SNR), Peak Signal to Noise Ratio (PSNR), dan Cross Correlation (CC) [1]. Sementara itu, pada penelitian ini akan dilakukan perbandingan kinerja filter FIR dan IIR, melalui dua filter spesifik bandpass Hamming Window dan bandpass Butterworth dalam prapemrosesan sinyal EEG untuk menghasilkan perhitungan daya dan entropi masing-masing jenis sinyal EEG. Perbandingan kinerja filter akan didasarkan pada parameter beda fasa, kestabilan filter dengan diagram pole-zero, SNR, dan juga waktu pemfilterannya.

Himpunan data EEG diperoleh, dikumpulkan, dan diuraikan menjadi beberapa jenis gelombang otak, seperti Gamma, Beta, Alpha, Theta, dan Delta. Berdasarkan tiap jenis gelombang tersebut, kemudian dilakukan analisis perhitungan daya dan entropi dari sinyal otak dengan sinyal EEG. Proses pemrograman, perhitungan matematis, serta analisis sinyal EEG akan dilakukan pada perangkat lunak MATLAB 2017.

Tujuan dari penelitian ini adalah menganalisis sinyal EEG dengan menggunakan filter IIR Butterworth dan filter FIR Hamming Window, kemudian kedua filter tersebut akan dibandingkan untuk melihat filter yang lebih baik dalam menghilangkan noise. 
II. LANDASAN TEORI

\section{A. Pra-pemrosesan Data Elektroensefalografi (EEG)}

Otak mengirimkan informasi dalam bentuk sinyal elektrik. Sinyal ini dapat terukur menggunakan bantuan elektroda-elektroda yang ditempelkan di kepala. Hasil atau data yang diperoleh melalui pengukuran ini disebut EEG atau elektroensefalografi. EEG menunjukkan ukuran perbedaan potensial listrik antara titik kulit kepala dan elektroda referensi [2]. Melalui EEG, dokter dapat mengetahui gangguan yang dialami oleh pasien. Namun, sinyal EEG sudah memiliki noise sejak data diambil dari sumbernya. Oleh karena itu, sinyal EEG perlu melewati tahap pengolahan yang disebut EEG Data Preprocessing sebelum dapat dianalisa dan diinterprestasikan dalam bentuk Brain-Computer Interface (BCI).

EEG Data Preprocessing perlu dilakukan agar data dapat siap digunakan untuk tahap analisa dan interpretasi. Meskipun begitu, tahap ini merupakan tahapan yang krusial. Apabila terjadi kesalahan dalam pengolahan data, informasi yang terkandung dalam sinyal tersebut dapat hilang. Dalam tahap ini, pemrosesan yang dilakukan adalah filtering. Proses ini memanfaatkan filter digital untuk menghilangkan noise dan mengekstrak informasi yang terdapat di dalam sinyal. Pada awalnya data EEG hanya dapat terukur setelah melalui penguat sinyal (amplifier) analog karena memiliki amplitudo yang sangat rendah, yaitu antara $10-100 \mu \mathrm{V}$. Kini, penguat sinyal yang digunakan adalah digital. Data yang ada diolah dalam bentuk sinyal sampel [2].

\section{B. Daya dan Entropi}

Dalam sistem EEG, daya digunakan untuk identifikasi alzheimer [3], analisis kondisi pikiran menggunakan spektral daya [4], dan entropi digunakan untuk menunjukkan kompleksitas melalui tingkat gangguan yang terjadi. Entropi sendiri mengandung informasi dan bersifat unik bagi setiap individu sehingga entropi dapat digunakan untuk mengidentifikasi orang. Pada sistem Brain-Computer Interface (BCI), entropi digunakan untuk mengukur tingkat gangguan di sistem. Persamaan yang digunakan untuk menunjukkan ukuran non-linier yang mengukur tingkat kerumitan dalam deret waktu disebut Shannon Entropy [5].

$$
H(X)=-c \sum_{i=0}^{m} p\left(x_{i}\right) \ln p\left(x_{i}\right)
$$

Perhitungan daya akan menggunakan rumus pembagian antara jumlah dari kuadrat magnitudo sinyal dengan panjang sinyal, seperti persamaan (2) berikut.

$$
\operatorname{Daya}(P)=\frac{\sum_{i=0}^{N} x(i)^{2}}{N}
$$

\section{Filter Digital}

Filter digital adalah algoritma matematika yang diterapkan pada perangkat keras ataupun perangkat lunak yang beroperasi untuk mencapai tujuan penyaringan. Secara garis besar, filter digital dibagi menjadi dua, yaitu Finite Impulse Response (FIR) dan Infinite Impulse Response (IIR). Perbedaan mendasar dari kedua jenis filter ini dapat dilihat pada tabel berikut [6].

\begin{tabular}{|c|c|}
\hline Filter FIR & Filter IIR \\
\hline $\begin{array}{l}\text { Dapat memiliki linear } \\
\text { phase response karena } \\
\text { tidak ada phase distortion } \\
\text { yang masuk ke dalam } \\
\text { sinyal oleh filter } \\
\end{array}$ & $\begin{array}{c}\text { Memiliki phase response yang } \\
\text { non-linear }\end{array}$ \\
\hline $\begin{array}{l}\text { Bila direalisasikan secara } \\
\text { non-rekursif, hasil filter } \\
\text { akan selalu stabil }\end{array}$ & $\begin{array}{l}\text { Hasil filter tidak terjamin akan } \\
\text { selalu stabil }\end{array}$ \\
\hline $\begin{array}{l}\text { Efek penggunaan sejumlah } \\
\text { bit pada penerapan filter, } \\
\text { seperti roundoff noise dan } \\
\text { coefficient quantization } \\
\text { errors, jauh lebih parah } \\
\text { dibandingkan dengan } \\
\text { penerapan IIR filters } \\
\end{array}$ & $\begin{array}{l}\text { Efek penggunaan sejumlah bit } \\
\text { pada penerapan filter, seperti } \\
\text { roundoff noise dan coefficient } \\
\text { quantization errors, lebih baik } \\
\text { dibandingkan dengan } \\
\text { penerapan FIR filters }\end{array}$ \\
\hline $\begin{array}{l}\text { Membutuhkan koefisien } \\
\text { yang lebih banyak untuk } \\
\text { filter cutoff yang tajam }\end{array}$ & $\begin{array}{c}\text { Membutuhkan koefisien yang } \\
\text { lebih sedikit untuk filter cutoff } \\
\text { yang tajam }\end{array}$ \\
\hline $\begin{array}{l}\text { Lebih mudah untuk } \\
\text { mensintesis filter dengan } \\
\text { arbitrary frequency } \\
\text { responses }\end{array}$ & $\begin{array}{l}\text { Lebih mudah untuk mengubah } \\
\text { filter analog menjadi filter } \\
\text { digital IIR }\end{array}$ \\
\hline
\end{tabular}

Tabel 1. Tabel perbedaan filter FIR dan filter IIR

Ada beberapa metode yang digunakan dalam menghitung koefisien FIR. Salah satu metode yang paling umum dan sering digunakan adalah window method. Dalam metode ini, terdapat 5 fungsi window yang memiliki karakteristik atau fitur yang berbeda. Kelima window function tersebut adalah Rectangular, Hanning, Hamming, Blackman, dan Kaiser. Pemilihan window function disesuaikan dengan karakteristik filter yang akan dibuat. Namun, diantara kelima jenis fungsi tersebut, Hamming merupakan jenis fungsi yang lebih sering digunakan. Selain itu, dari hasil penelitian menyatakan bahwa diantara kelima jenis filter dengan teknik windowing yang terbaik adalah tipe Hamming Window untuk nilai orde yang sama [7].

Filter digital IIR dibuat melalui penurunan fungsi transfer dari filter analog klasik dengan karakteristik Butterworth, Chebyshev, atau Elliptic. Perbedaan dari ketiga filter analog ini ada pada ripple yang terbentuk dan roll-off rate dimana hal ini menunjukkan laju penurunan gain. Gambar di bawah ini menunjukkan perbedaan respon frekuensi dari masing-masing filter analog digital [8]. 

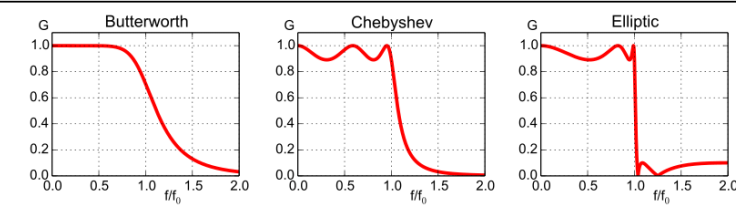

Gambar 1. Perbedaan respon frekuensi filter analog digital

Filter Butterworth memiliki respon amplitudo passband yang hampir datar (maximally flat) dan tidak memiliki riak sehingga relatif lebih baik daripada filter Chebyshev dan Elliptic yang juga termasuk desain filter yang umum digunakan [9].

Maka dari itu, dalam penelitian ini, filter yang akan digunakan adalah jenis filter Butterworth dan Hamming. Pemilihan kedua jenis filter ini bertujuan untuk membandingkan kualitas hasil filtering dari filter digital IIR dan FIR. Selain itu, pemilihan orde 5 untuk filter Butterworth didasarkan pada peneliatan yang sudah ada [10], berkaitan dengan pemrosesan sinyal EEG. Serta, pemilihan orde yang sama pada filter Hamming Window bertujuan mempermudah perbandingan kedua filter.

\section{Discrete Wavelet Decomposition (DWT)}

Berdasarkan hasil penelitian [11], Discrete Wavelet Decomposition (DWT) dengan jenis Daubechies 4 merupakan jenis yang dapat menghilangkan noise dari sinyal EEG yang paling efisien. Kemudian penggunaan orde 8 dipilih karena paling tepat untuk proses penghilangan noise pada sinyal EEG dan juga berdasarkan frekuensi noise dan baseline yang terdapat pada sinyal EEG yang ingin dihilangkan [12]. Metode DWT juga digunakan untuk memisahkan sinyal EEG menjadi sinyal Gamma, Beta, Alfa, Theta dan Delta. Orde 6 dipilih pada langkah ini dengan menyesuaikan rentang frekuensi masingmasing jenis sinyal yang ingin dipisahkan.

\section{METODOLOGI DAN IMPLEMENTASI}

Adapun langkah-langkah pra-pemrosesan sinyal EEG yang akan diimplementasikan ke dalam MATLAB adalah sebagai berikut:

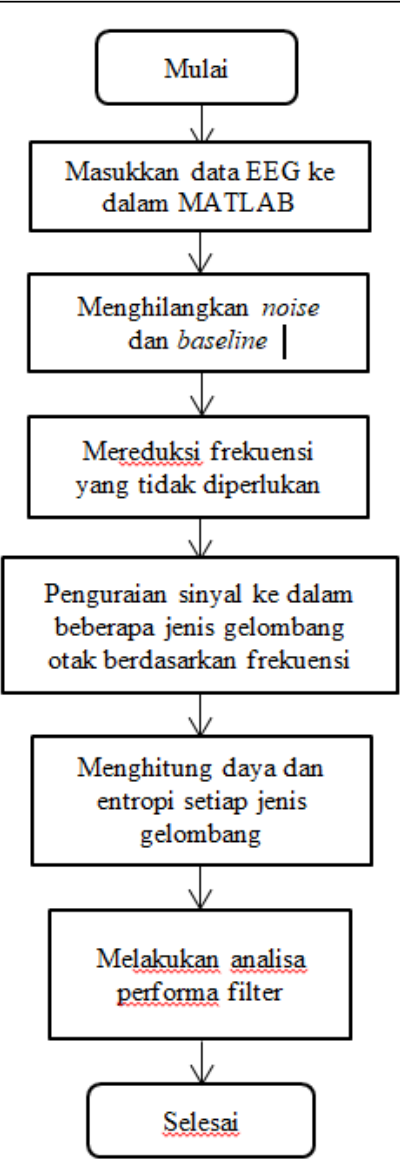

Gambar 2. Diagram blok proses pra-pemrosesan sinyal EEG dengan menggunakan perangkat lunak

MATLAB

\section{A. Menginput Data EEG ke dalam MATLAB}

Pada langkah pertama, data mentah diperoleh dari tim investigator Children's Hospital Boston (CHB) dan Massachusetts Institute of Technology (MIT) yang dilampirkan pada database website PhysioNet [13]. Sampel sinyal yang diperoleh sebesar 256 sampel per detik yang menunjukkan bahwa data ini masih berupa domain waktu sehingga diperlukan pengkonversian data sinyal domain waktu ke domain frekuensi terlebih dahulu.

Oleh karena itu, dalam pengkonversian data sinyal domain waktu menjadi frekuensi sampling $256 \mathrm{~Hz}$, yaitu dengan metode Fast Fourier Transform (FFT), yang lebih cepat dan efisien.

\section{B. Menghilangkan Noise dan Baseline}

Berdasarkan hasil plot data sinyal EEG dari langkah pertama sebelumnya, terlihat bahwa gelombang EEG masih terdapat banyak kebisingan (noise) yang akan mengganggu pemrosesan sinyal pada tahap selanjutnya. Noise ini dapat disebabkan oleh aktivitas subyek individu, yakni akibat pergerakan pada mata, otot, dan jantung, yang 
ditandai dengan adanya siklus naik-turun pada gelombang yang tidak konsisten pada garis isoline atau garis nol, yang juga disebut dengan baseline [14-15].

Oleh karena itu, sebagai langkah kedua, kami perlu mengimplementasikan teknik reduksi kebisingan (denoising), dimana proses ini berperan penting dalam mendapatkan hasil sinyal yang bersih dan lebih akurat, tanpa menghilangkan informasi penting yang diperlukan. 1-D wavelet decomposition adalah metode yang dipilih untuk digunakan dalam proses denoising, dimana nilai level of decomposition adalah 8, dan wname db4 (order 4 Daubechies wavelet).

\section{Mereduksi Frekuensi yang Tidak Diperlukan}

Langkah ketiga yaitu melakukan reduksi sinyal frekuensi pada gelombang sinyal EEG dengan tipe bandpass filter, yang hanya akan melewatkan sinyal pada frekuensi diantara nilai frekuensi cutoff $\mathrm{w}_{1}$ dan nilai frekuensi cutoff $\mathrm{w}_{2}$. Pada penelitian ini, kami hanya ingin mengambil sinyal di antara $0.1-35 \mathrm{~Hz}$. Sehingga, pada MATLAB kami menggunakan normalisasi nilai $\mathrm{w}_{1}=0.1 * 2 /$ fs dan normalisasi $\mathrm{w}_{2}=$ $35 * 2 /$ fs, dengan nilai orde filter (n) sebesar 5 .

Pengimplementasian akan dilakukan dengan menggunakan dua jenis filter sebagai perbandingan, yaitu filter desain Finite Impulse Response (FIR) dengan metode Hamming Window dan filter IIR Butterworth.

D. Penguraian Sinyal ke dalam Beberapa Jenis Gelombang Otak Berdasarkan Frekuensi

Ada 5 jenis gelombang otak berdasarkan frekuensinya, yaitu Gamma $(16 \mathrm{~Hz}-100 \mathrm{~Hz})$ yang terjadi pada saat seseorang sedang melakukan aktivitas mental yang sangat tinggi dengan kesadaran penuh; Beta $(12 \mathrm{~Hz}-19 \mathrm{~Hz})$ terjadi pada saat seseorang sedang berada aktivitas mental yang terjaga penuh dan didominasi oleh pemikiran logika; Alpha $(8 \mathrm{~Hz}-12 \mathrm{~Hz})$ yang terjadi apabila seseorang dalam kondisi relaksasi; Theta $(4 \mathrm{~Hz}-7 \mathrm{~Hz})$ terjadi ketika seseorang sedang tidur ringan atau sangat mengantuk; dan Delta $(0.5 \mathrm{~Hz}-4 \mathrm{~Hz})$ yang terjadi saat seseorang tertidur lelap tanpa adanya mimpi [16].

Penguraian sinyal ini penting untuk dilaksanakan karena akan diimplementasikan pada kehidupan, khususnya bidang kedokteran untuk memantau aktivitas, mengevaluasi, dan melacak adanya perubahan fungsi otak pada pasien. Oleh karena itu, pada langkah keempat, kami akan menggunakan metode wavelet Daubechies 4 orde 6.

\section{E. Menghitung Daya dan Entropi Setiap Jenis Gelombang}

Langkah kelima sekaligus langkah terakhir dalam penelitian ini, adalah melakukan analisa perhitungan daya dan entropi terhadap tiap jenis gelombang, baik yang melalui proses filter IIR Butterworth maupun filter desain FIR dengan metode Hamming window. Hasil perhitungan ini akan dimanfaatkan oleh tenaga medis untuk mempermudah dan mendukung hasil diagnosis EEG seperti yang telah dilakukan pada langkah ke-4.

Pengimplementasian proses perhitungan daya dan entropi pada setiap jenis gelombang, akan menggunakan dua proses yang berbeda. Untuk melakukan perhitungan entropi pada MATLAB, digunakan metode wentropy (entropy wavelet packet) dengan tipe entropi Shannon.

\section{F. Melakukan Analisa Performa Filter}

Sebagai langkah tambahan sebagai pembanding untuk mengetahui sifat sinyal hasil pemfilteran masing-masing jenis filter, dilakukan perhitungan mengenai perbedaan fasa dan rasio amplitudo antara sinyal masukan filter dengan keluarannya, pengujian kestabilan dengan analisa diagram pole-zero, perhitungan Signal-to-Noise Ratio (SNR), dan lama waktu pemfilteran yang dilihat melalui running time pada MATLAB.

Perhitungan perbedaan fasa sinyal dilakukan dengan fungsi max yang diberi input berupa sinyal Transformasi Fourier dan mengembalikan nilai frekuensi maksimum sinyal dan indeksnya. Nilai tersebut kemudian digunakan untuk menghitung besar fasa sinyal dengan fungsi angle. Perbedaan fasa didapatkan dari pengurangan nilai fasa sinyal masukan dan sinyal keluaran filter. Sedangkan, rasio amplitudo didapat dengan membagi ampitudo maksimum sinyal keluaran terhadap amplitudo maksimum sinyal masukkan filter.

Pengujian kestabilan filter akan digunakan diagram pole-zero sistem waktu diskrit untuk fungsi transfer filter bandpass dimana nilai b merupakan koefisien numerator dan a merupakan koefisien denominator. Sementara itu, perhitungan SNR akan dilakukan dengan menggunakan metode pengembalian SNR dalam bentuk desibel sinyal yang didapatkan dengan menghitung perbandingan total kuadrat magnitude sinyal $\mathrm{x}$ terhadap noise $\mathrm{y}$.

\section{HASIL DAN ANALISIS}

Data mentah yang didapatkan dari himpunan data Children's Hospital Boston (CHB) dan Massachusetts Institute of Technology (MIT) merupakan data pengukuran sinyal EEG pada subjek selama 1 jam [12]. Pada penelitian ini data sinyal yang digunakan dibatasi mulai dari detik ke-0 sampai detik ke-20. Sinyal tersebut kemudian ditransformasikan dengan Fast Fourier Transfom (FFT) untuk menampilkan spektrum frekuensi sinyal seperti pada Gambar 3. 


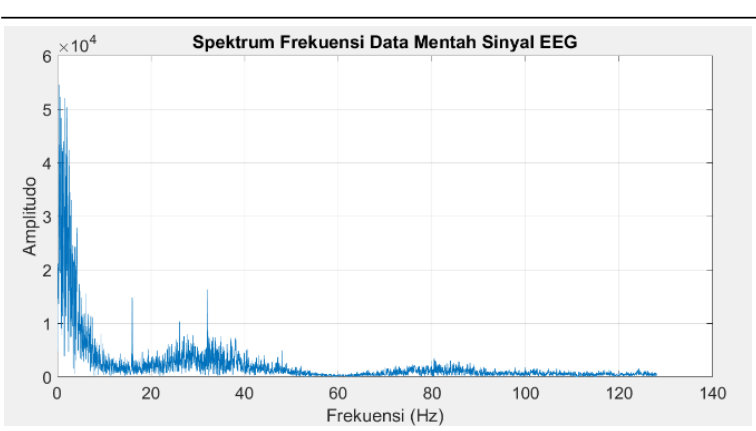

Gambar 3. Spektrum frekuensi sinyal mentah

Dari spektrum frekuensi sinyal di atasdiketahui bahwa frekuensi yang terdapat pada data memiliki rentang $0 \mathrm{~Hz}$ hingga $128 \mathrm{~Hz}$, sedangkan sinyal utama yang berisis informasi yang dibutuhkan memiliki frekuensi sebesar $0,1 \mathrm{~Hz}-35 \mathrm{~Hz}$. Hal ini mengindikasikan keberadaan noise pada sinyal.

Secara umum, aktivitas biologis seperti detak jantung, pergerakan kelopak mata, dan otot lainnya akan menghasilkan noise pada data sinyal EEG berupa efek baseline dan sinyal berfrekuensi tinggi. Kedua jenis noise tersebut perlu dihilangkan agar tidak mengganggu proses analisis sinyal EEG. Untuk menghilangkan efek baseline sinyal, dimanfaatkan Discrete Wavelet Transform (DWT) Daubechies 4 dengan orde 8 . Hasil penghilangan noise dan baseline sinyal dan segment hasil proses untuk membantu memperlihatkan sinyal sebelum dan sesudah proses dapat dilihat pada Gambar 4.

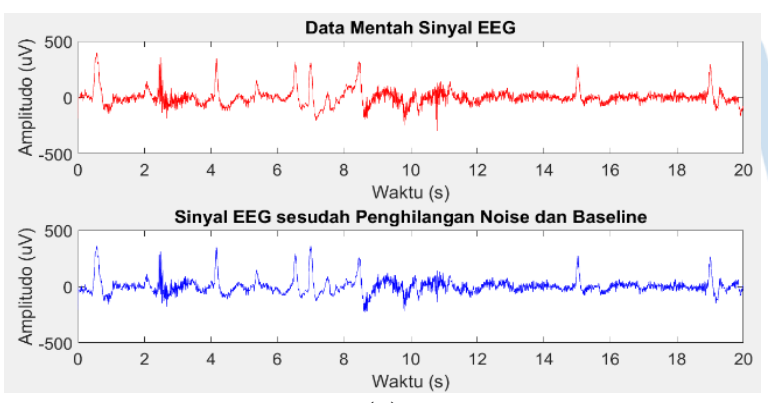

(a)

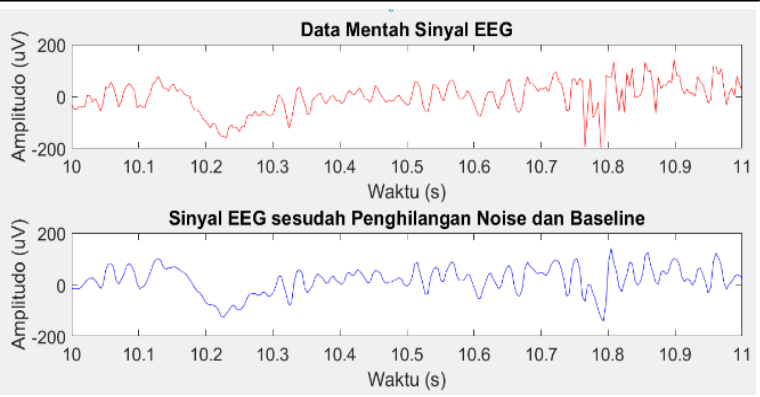

(b)

Gambar 4. (a) Hasil proses penghilangan noise dan efek baseline dengan segment hasil proses selama 1 detik; (b) Hasil proses penghilangan noise dan efek baseline yang di perbesar (untuk melihat perbedaan lebih detail)

Selanjutnya, untuk noise yang memiliki frekuensi tinggi akan dihilangkan dengan bantuan filter digital. Pada tahap ini, diimplementasikan dua jenis filter; yakni filter Infinite Impulse Response (IIR) jenis Butterworth dengan orde 5 dan filter Finite Impulse Response (FIR) jenis Hamming window dengan orde yang sama. Orde filter dipilih berdasarkan referensi penelitian lain yang juga memproses sinyal EEG. Selain itu, dalam pengimplementasian filter Butterworth, untuk megkompensasi karakteristik filter yang cenderung menyebabkan perubahan fasa pada sinyal output, maka digunakan fungsi filtfilt yang dapat membantu meminimalisir distorsi fasa sinyal akibat filter IIR. Perbandingan sinyal input dan hasil pemfilteran kedua jenis filter ditunjukkan pada Gambar 5 dan spektrum fekuensinya pada Gambar 6.

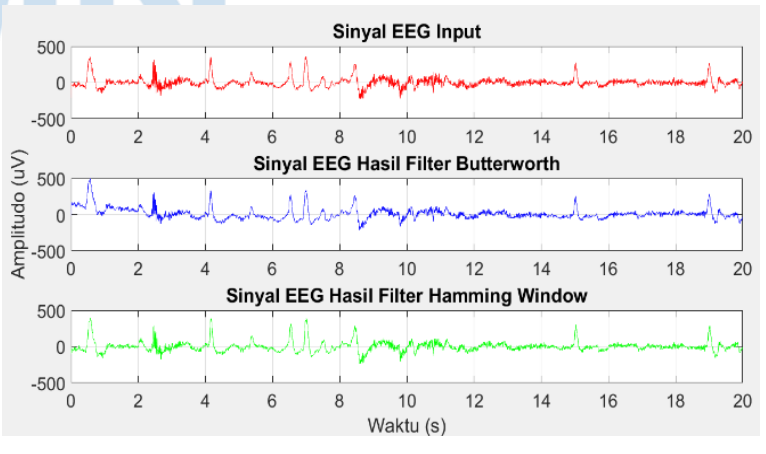

Gambar 5. Hasil pemfilteran sinyal EEG dengan filter Butterworth IIR dan filter Hamming Window FIR 


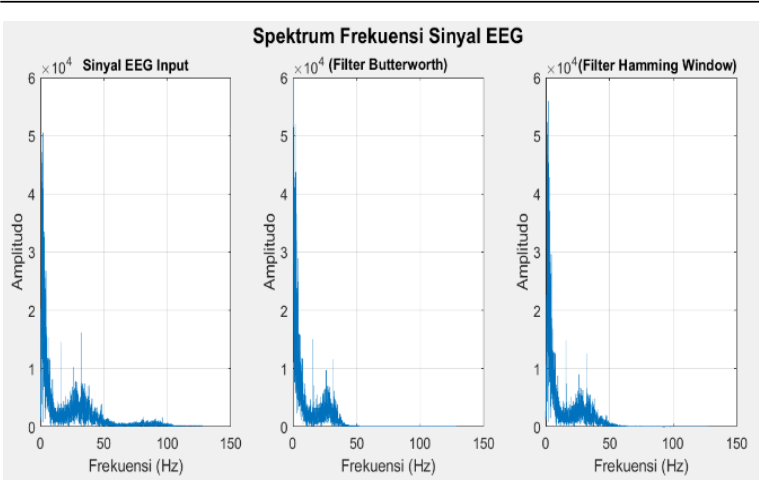

Gambar 6. Spektrum frekuensi sinyal hasil pemfilteran sinyal EEG dengan filter Butterworth IIR dan filter Hamming Window FIR

Apabila dilihat dari grafik, di awal data terdapat perbedaan amplitudo antara sinyal keluaran filter Butterworth dan filter Hamming window. Selain itu, dilihat dari spektrum frekuensinya, filter Butterworth memiliki transisi yang lebih tajam dibanding filter Hamming window pada orde yang sama. Pada filter Butterworth dengan frekuensi cutoff yang ditentukan sebesar $35 \mathrm{~Hz}$, transisi terjadi hingga frekuensi $44 \mathrm{~Hz}$, sedangkan pada filter Hamming Window transisi terjadi hingga frekuensi $62 \mathrm{~Hz}$. Dari hasil perhitungan, kedua filter diketahui menimbukan distorsi fasa terhadap sinyal, namun perbedaan fasa yang disebabkan oleh filter Hamming Window jauh lebih kecil dibandingkan dengan filter Butterworth. Perbedaan fasa pada sinyal EEG dapat menyebabkan gangguan timing informasi antara berbagai frekuensi pada sebuah sinyal atau pada dua sinyal berbeda. Distorsi dari timing informasi dapat menyebabkan misinterpretasi hasil dan kekeliruan konklusi analisis sinyal [17].

Tabel 2. Perbedaan fasa dan rasio amplitudo filter

\begin{tabular}{|c|c|c|}
\hline Jenis Filter & $\begin{array}{c}\text { Beda Fasa } \\
\text { (Radian) }\end{array}$ & $\begin{array}{c}\text { Rasio } \\
\text { Amplitudo }\end{array}$ \\
\hline $\begin{array}{c}\text { Butterworth } \\
\text { IIR }\end{array}$ & 0.211 & 0.553 \\
\hline $\begin{array}{c}\text { Hamming } \\
\text { Window FIR }\end{array}$ & 0.090 & 0.921 \\
\hline
\end{tabular}

Analisa performa filter yang kedua, dilakukan dengan menguji kestabilan dari kedua filter dengan analisa poles dan zeros. Ketidakstabilan filter dapat menyebabkan output yang dihasilkan filter tidak sesuai dengan fungsi input dan mengindikasikan kecendrungan osilasi output filter. Filter dikatakan stabil apabila jarak poles filter dari origin bernilai kurang dari satu, ditandai dengan lingkaran satuan. Pada diagram pole-zero filter Butterworth (Gambar 7), terdapat pole yang berada pada lingkaran satuan yang artinya ke origin adalah 1 sehingga desain filter Butterworth pada penelitian ini dinyatakan tidak stabil.

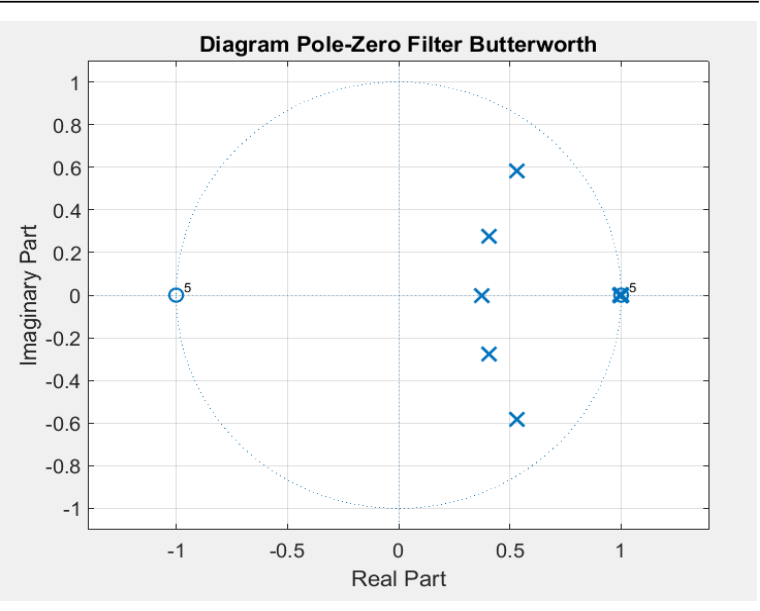

Gambar 7. Diagram pole-zero filter Butterworth

Sedangkan pada analisa diagram pole-zero filter Hamming Window (Gambar 8), letak pole filter berada pada titik origin sehingga dapat dikatakan desain filter pada penelitian ini bersifat stabil.

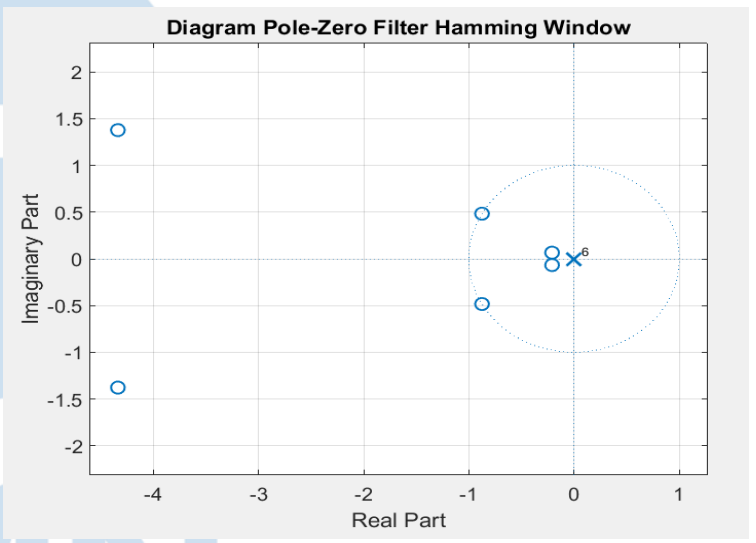

Gambar 8. Diagram pole-zero filter Hamming Window

Analisa ketiga dengan menggunakan Signal-toNoise Ratio (SNR) merupakan perbandingan antara level sinyal yang dibutuhkan dengan level noise yang terdapat pada sinyal. Nilai karakteristik SNR dari sinyal yang akan digunakan untuk menghitung daya dan entropi dari hasil pemfilteran dengan filter Butterworth dan Hamming Window ditunjukkan pada Tabel 3. Diantara kedua filter, filter yang memiliki nilai SNR yang lebih besar adalah filter Hamming Window sehingga dapat dikatakan menurut parameter SNR, filter yang lebih baik kinerjanya adalah filter Hamming Window.

Tabel 3. Nilai Signal-to-Noise ratio filter

\begin{tabular}{|c|c|}
\hline SNR Filter Butterworth & $\begin{array}{c}\text { SNR Filter Hamming } \\
\text { Window }\end{array}$ \\
\hline $5,3836 \mathrm{~dB}$ & $5,6029 \mathrm{~dB}$ \\
\hline
\end{tabular}


Dari segi waktu yang diperlukan untuk pemfilteran sinyal yang dihitung dengan fungsi running time MATLAB. Data running time dihitung dengan menjalankan program di tiga hardware berbeda dan dirata-ratakan untuk melihat kecenderungan hasil running time. Filter Butterworth memerlukan waktu eksekusi selama 0,002266 sekon, lebih singkat dari waktu yang diperlukan unuk eksekusi program dengan filter Hamming Window yakni selama 0,006062 sekon.

Setelah pemfilteran sinyal, proses selanjutnya adalah penguraian sinyal EEG menjadi lima jenis gelombang; Gamma, Beta, Alpha, Theta, dan Delta. Penguraian sinyal dilakukan dengan DWT Daubechies 4 orde 6 , menyesuaikan dengan klasifikasi gelombang otak dan batas frekuensinya. Hasil penguraian terdapat pada Gambar 9 dan Gambar 10. Terdapat perbedaan amplitudo pada hasil penguraian sinyal yang diproses dengan filter yang berbeda. Pada kasus ini, gelombang Gamma, Beta, dan Theta dari sinyal yang difilter dengan filter Butterworth memiliki amplitudo yang relatif lebih tinggi dibandingkan dengan gelombang Gamma dari sinyal yang difilter dengan Hamming Window.

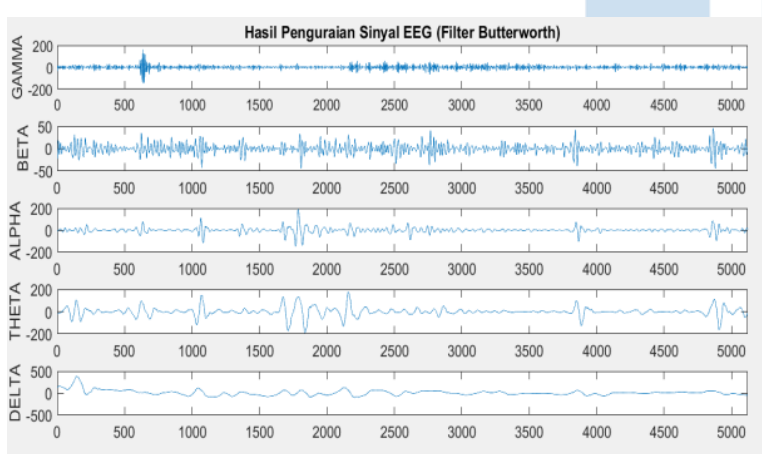

Gambar 9. Hasil penguraian sinyal yang sudah difilter dengan filter Butterworth

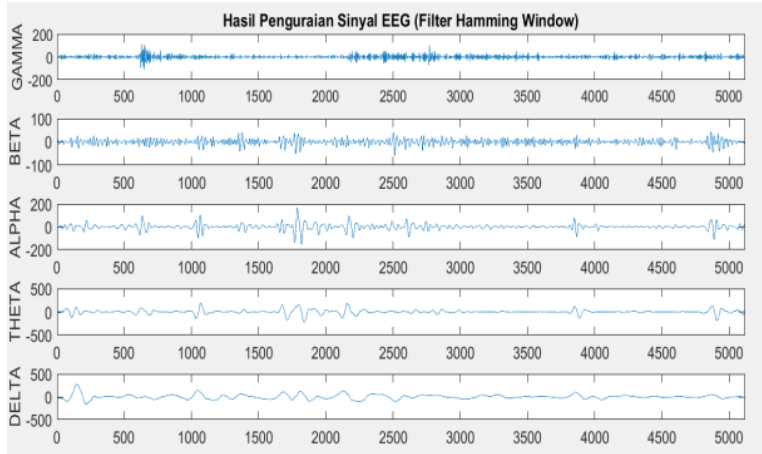

Gambar 10. Hasil penguraian sinyal yang sudah difilter dengan filter Hamming Window
Akibat dari perbedaan amplitudo hasil penguraian sinyal otak berefek pada hasil perhitungan daya dan entropi sinyal. Nilai daya dan entropi sinyal EEG ditunjukkan pada Tabel 3 dan Tabel 4.

Tabel 4. Hasil perhitungan daya sinyal EEG

\begin{tabular}{|c|c|c|}
\hline \multirow{2}{*}{$\begin{array}{c}\text { Klasifikasi } \\
\text { Gelombang }\end{array}$} & \multicolumn{2}{|c|}{ Daya (mW) } \\
\cline { 2 - 3 } & Butterworth IIR & $\begin{array}{c}\text { Hamming Window } \\
\text { FIR }\end{array}$ \\
\hline Gamma & 0,208 & 0,1778 \\
\hline Beta & 0,087 & 0,103 \\
\hline Alpha & 0,541 & 0,573 \\
\hline Theta & 1,49 & 1,754 \\
\hline Delta & 3,607 & 2,26 \\
\hline
\end{tabular}

Tabel 5. Hasil perhitungan entropi sinyal EEG

\begin{tabular}{|c|c|c|}
\hline \multirow{2}{*}{$\begin{array}{c}\text { Klasifikasi } \\
\text { Gelombang }\end{array}$} & \multicolumn{2}{|c|}{ Entropi } \\
\cline { 2 - 3 } & Butterworth IIR & $\begin{array}{c}\text { Hamming Window } \\
\text { FIR }\end{array}$ \\
\hline Gamma & $-7,331 \times 10^{6}$ & $-5,931 \times 10^{6}$ \\
\hline Beta & $-2,490 \times 10^{6}$ & $-3,027 \times 10^{6}$ \\
\hline Alpha & $-22,89 \times 10^{6}$ & $-24,037 \times 10^{6}$ \\
\hline Theta & $-68,459 \times 10^{6}$ & $-82,217 \times 10^{6}$ \\
\hline Delta & $-179,256 \times 10^{6}$ & $-104,044 \times 10^{6}$ \\
\hline
\end{tabular}

Hasil rangkuman perhitungan nilai daya dan entropi sinyal dapat dilihat pada Gambar 11 dan Gambar 12.

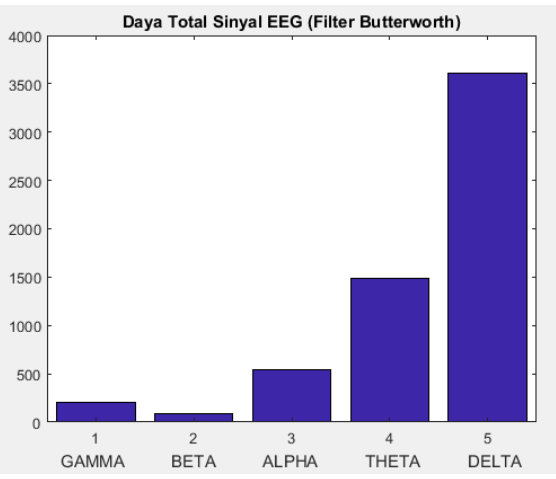

(a) 


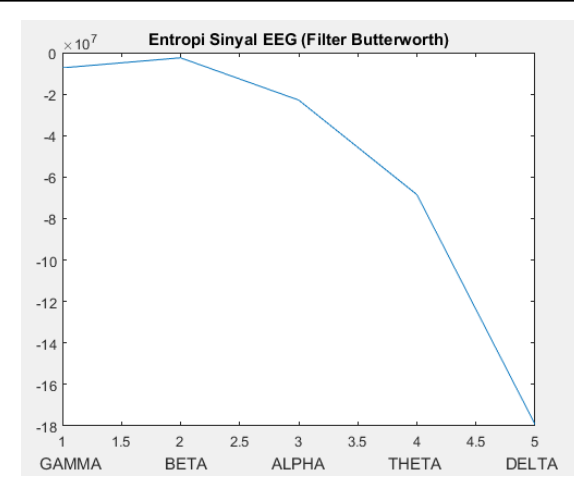

(b)

Gambar 11. Nilai daya (a) dan entropi (b) sinyal EEG yang difilter dengan filter Butterworth

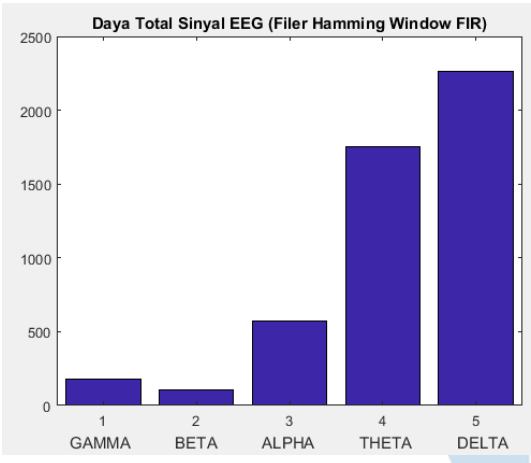

(a)

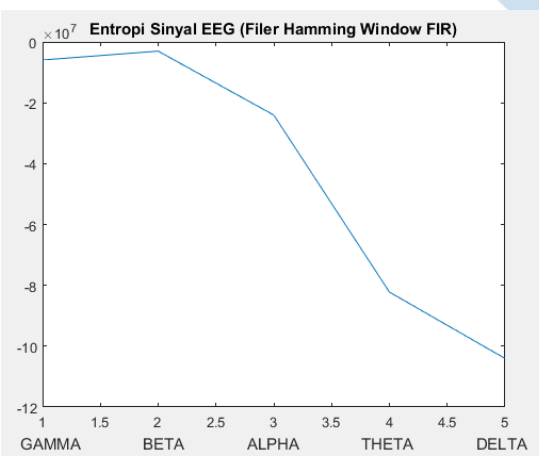

(b)

Gambar 12. Nilai daya (a) dan entropi (b) sinyal EEG yang difilter dengan filter Hamming Window

Nilai daya dan entropi sinyal EEG ini merupakan acuan yang dimanfaatkan untuk mendiagnosa penyakit tertentu, seperti epilesi. Dari hasil simulasi, dilihat bahwa nilai daya total dan entropi memiliki perbedaan akibat pemilihan filter. Hal dapat menunjukkan bahwa ketidaktepatan dalam pemilihan filter dapat berpengaruh besar terhadap proses diagnosa melalui sinyal EEG.

\section{SimpUlaN}

Berdasarkan hasil implementasi Hamming Window FIR dan filter Butterworth IIR ke dalam rangkaian prapemrosesan sinyal EEG, dapat disimpulkan bahwa, filter Butterworth IIR dan filter Hamming Window menunjukkan performa pemfilteran sinyal pada orde yang sama memiliki hasil yang berbeda tergantung parameternya. Filter Butterworth memiliki transisi yang lebih tajam dan waktu pemrosesan yang lebih cepat dibandingkan dengan filter FIR Hamming Window, akan tetapi distorsi fasanya lebih besar dan filter cenderung tidak stabil. Pada filter Hamming Window FIR memiliki nilai SNR yang lebih baik, dan filternya bersifat stabil. Sehingga disimpulkan bahwa berdasarkan parameter pertimbangan distorsi fasa, kestabilan, SNR, dan waktu pemrosesan, untuk menghasilkan sinyal EEG untuk diagnosa yang akurat dan dengan output filter yang stabil, maka lebih dianjurkan pemilihan filter Hamming Window FIR.

Namun dikarenakan dalam ilmu kedokteran hasil EEG yang ingin ditinjau berupa hasil daya dan entropi, sementara hasil penggunaan kedua jenis filter yang telah dilakukan dalam pra-pemrosesan sinyal EEG pada kasus ini memiliki perbedaan hasil yg cukup signifikan. Sehingga pada penilitian kedepannya, direkomendasikan untuk melakukan pengkajian lebih lanjut mengenai daya dan entropi pada otak.

\section{DAFTAR PUSTAKA}

[1] A. Khatter, R. Mahajan, and D. Bansal, "Performance Analysis of IIR \& FIR Windowing Techniques in Electroencephalography Signal Processing," VOLUME-8 ISSUE-10, AUGUST 2019, REGULAR ISSUE International Journal of Innovative Technology and Exploring Engineering, vol. 8 , no. 10 , pp. $3568-3578$, Oct. 2019

[2] M. Clerc, L. Bougrain and F. Lotte, Brain-Computer Interfaces 1 : Foundations and Methods, Great Britain: ISTE Ltd, 2016.

[3] R. Wang, J. Wang, H. Li, and Y. Chen, "Power spectral density and high order bispectral analysis of Alzheimers EEG," The 27th Chinese Control and Decision Conference (2015 CCDC), 2015.

[4] J. Culpepper, "Discriminating mental states using EEG represented by power spectral density," 1999.

[5] Barkatullah and A. Khurshid, "Entropy and power analysis of brain signal data by EEG signal processing," International Journal of Engineering Development and Research, Faridabad, 2016

[6] E. C. Ifeachor and B. W. Jervis, Digital Signal Processing : A Practical Approach, 2nd ed., England: Pearson Education Limited, 2002.

[7] T. Pangaribuan, "Desain filter digital dengan teknik windowing pada simulasi berbasis MATLAB," Jurnal Fakultas Teknik, 2015.

[8] Laghari, W.M., Baloch, M.U., Mengal, M.A. and Shah, S.J. 2014. Performance Analysis of Analog Butterworth Low Pass Filter as Compared to Chebyshev Type-I Filter, Chebyshev Type-II Filter and Elliptical Filter. Circuits and Systems, Vol. 5, 209-216.

[9] Farzana Yesmin, "Difference between Butterworth, Chebyshev, and Elliptic Filter", ResearchGate, 2014. 
[10] D. Harris "Engineering Psychology and Cognitive Ergonomics: Performance, Emotion and Situation Awareness," Faculty of Engineering and Computing, 2017.

[11] Md. Mamun, M. Al-kadi, and M. Marufizzaman, "Effectiveness of wavelet denoising on electroencephalogram signals," SIenceDirect, 2013.

[12] R. R. Ranganatan V. "Evaluation Effect of Unsepervised Dimentionality Reduction Techniques on Automated Arrhythmia Classification," Biomed Signal Process Control, 2017.

[13] CHB-MIT Scalp EEG Database, PhysioNet, 2010.
[14] Janner. Simarmata, Mardi Turnip, Arjon Turnip, "Denoising Artefak pada Sinyal Elektroensefalogram (EEG) Menggunakan FIR Filter dengan Metode Transformasi Wavelet", in SNITI 2014, ResearchGate.

[15] Iman Fahruzi, "Mengurangi Pengaruh Noise Baseline Wander pada Sinyal Elektrocardiogram (ECG)", Teknik Elektro, Politeknik Negeri Batam.

[16] Y. Akbar, "Pola gelombang otak abnormal pada elektroenchepalograph", ResearchGate, 2014.

[17] D. Yael, J. J. Vecht, and I. Bar-Gad, "Filter-Based Phase Shifts Distort Neuronal Timing Information," eneuro, vol. 5, no. 2,2018 